\title{
WIZYGOCI W REJONIE BAŁKANÓW W TEORII I PRAKTYCE POLITYCZNEJ DWORÓW PÓŹNEGO CESARSTWA RZYMSKIEGO
}

Obecność plemion gockich w rejonie Bałkanów datowana od co najmniej poł. IV aż po koniec $\mathrm{V}$ w. i ich znaczenie dla polityki obydwóch części późnego Cesarstwa Rzymskiego stanowi problem badawczy wymagający publikacji o wiele szerszej niż na to pozwalają ramy naukowego artykułu, warto jednak pokusić się o zasygnalizowanie najważniejszych problemów politycznych, militarnych i gospodarczych, z którymi musiały się skonfrontować rządy obydwóch części cesarstwa w związku z pojawieniem się Gotów na terenach bałkańskich. Możliwe, że wskazanie ciągle jeszcze otwartych pytań i usystematyzowanie problematyki będzie impulsem dla powstania szerszego, monograficznego omówienia ,problemu gockiego na Bałkanach”.

Patrząc na kolejne wydarzenia i zmieniające się znaczenie plemion gockich, jak też na różne koncepcje polityczne, jakie powstawały w Konstantynopolu i Rawennie w związku z obecnością tych plemion w rejonie Bałkanów można pokusić się o wstępne usystematyzowanie pewnych faz kształtowania się stosunku władz rzymskich do narastającego problemu związanego z wizygockimi migracjami w regionie. Bardzo ogólnie można wyróżnić trzy takie fazy:

- Faza wrogości i powstrzymywania - okres wojen gockich cesarza Walensa (328-378, cesarz od 364), rzymskie próby wywierania nacisku ekonomicznego i zamykająca tę fazę próba dyplomatycznego uregulowania wzajemnych stosunków podjęta w ramach rokowań pomiędzy cesarzem Walensem a ,sędzią” Atanarykiem (†381);

- Faza mniej lub bardziej kontrolowanej imigracji i różnorodne próby racjonalnego „zagospodarowania” z korzyścią dla cesarstwa znaczącej liczby przybyszów - przejście granicy Dunaju, pierwsze nieudane próby przejęcia kontroli nad migracją, katastrofa pod Adrianopolem, Teodozjański foedus;

* Prof. dr hab. Marek Wilczyński - Kierownik Katedry Historii Starożytnej w Instytucie Historii na Wydziale Humanistycznym Uniwersytetu Pedagogicznego im. Komisji Edukacji Narodowej w Krakowie; e-mail: wilczynski.m@wp.pl. 
- Faza konfrontacji i prób rozwiązania problemu - Wizygoci Alaryka I (365/370? - 411, król od 395) jako narzędzie polityki Konstantynopola i Rawenny, czy raczej jako samodzielny faktor polityczny?

Oczywiście militarne i handlowe kontakty pomiędzy Rzymianami a Gotami występują na długo przed połową IV wieku. Z różnym skutkiem walczyli z gockimi rabunkowymi inwazjami cesarze III w. np. Decjusz (ok. 200-251, cesarz od 249), Klaudiusz II zwany Gockim (214-270, cesarz od 368), Aurelian (214-275, cesarz od 270) czy Probus (232-282, cesarz od 276). Już w tym wczesnym okresie kontaktów Goci stanowili na bałkańskim pograniczu ważny element rzymskiej polityki. Nie chodzi jedynie o zagrożenie militarne, ale także o znaczące zmiany ekonomiczne, zachodzące skutkiem udanych napaści rabunkowych, napływu pieniędzy z wykupów lub handlu niewolnikami ${ }^{1}$ i ewentualnych kwot wypłacanych plemionom barbarzyńskim w celu powstrzymania ich od napaści, lub za świadczone przez nie wsparcie militarne. Wzrost zamożności i ułatwiony dostęp do luksusowych dóbr konsumpcji w sposób oczywisty musiał, wbrew intencjom Rzymian, wzmacniać motywację arystokracji plemiennej i wolnych Gotów do zwiększenia materialnych korzyści, co oznaczało nasilenie, a nie osłabienie nacisku na bałkańskie granice ${ }^{2}$. Osobnym problemem były gockie morskie wyprawy łupieżcze, także częściowo dotykające terenów bliskich Bałkanom. Oprócz zniszczeń i uprowadzania lokalnej ludności w niewolę powodowały one znaczące straty materialne i umożliwiały Gotom przejmowanie rzymskich depozytów pieniężnych, zasobów kruszcu, a nawet wyposażenia mennic ${ }^{3}$. $Z$ drugiej strony złakniona nowych zaciągów rekruta armia rzymska chętnie korzystała z barbarzyńskich kontyngentów. Goci pojawiają się dość wcześnie w szeregach rzymskich - już za czasów Gordiana III (225-244, cesarz od 238) regularne posiłki gockie walczyły na froncie wschodnim, co potwierdza inskrypcja

${ }^{1} \mathrm{O}$ absolutnym braku skrupułów rzymskich handlarzy niewolników, którzy bez żadnych oporów kupowali od barbarzyńców uprowadzonych w niewolę Rzymian, cieszących się przed porwaniem statusem ludzi wolnych, a nawet obywateli przekonany był Edward A. Thompson (22 V 1914 - 1 I 1994) - Barbarian Invaders and Roman Collaborators, „Florilegium” 2 (1980) 72.

${ }^{2}$ Por. G.M. Berndt, Aktionsradien gotischer Kriegergruppen, „Frühmittelalterliche Studien” 47 (2014) 15nn; tenże, Beute, Schutzgeld und Subsidien. Formen der Aneignung materieller Güter in gotischen Kriegsgruppen, w: Lohn der Gewalt. Beutepraktiken von der Antike bis zur Neuzeit, ed. H.C.J. Bömelburg, Krieg in der Geschichte 72, Paderborn 2011.

${ }^{3}$ Szerzej na temat gockich wypraw morskich w III w., por. A. Schwarcz, Die gotischen Seezüge des 3. Jahrhunderts, w: Die Schwarzmeerküste in der Spätantike und im frühen Mittelalter, hrsg. von R. Pillinger - A. Pülz - H. Vetters, Schriften der Balkan-Kommission. Antiquarische Abteilung 18, Wien 1992, 47-57. Na temat napływu monet i kruszcu do Barbaricum skutkiem barbarzyńskich najazdów rabunkowych z bogatej literatury na szczególne polecenie zasługują: Aleksander Bursche (The Battle of Abritus, the Imperial Treasury and Aurei in Barbaricum, „The Numismatic Chronicle" 173:2013, 151-170) oraz Gijsa De Greef (Romain Coin Hoards and Germanic Invasions AD 252-269. A Study of the Western Hoards from the Reigns Valerian, Gallienus and Postumus, „Revue Belge de Numismatique et de Sigillographie" 148:2002, 41-99). 
z Naqs-i Rustam ${ }^{4}$. Zdaniem Guido M. Berndta można mówić o pewnym, w miarę stałym, scenariuszu działania grup wojowników gockich we wczesnej fazie gocko-rzymskich stosunków na pograniczu naddunajskim. Najpierw grupy gockich wojowników wkraczają na tereny cesarstwa, stosując przemoc i gwałt głównie wobec ludności cywilnej, co prowokuje cesarskie wojska do kontrakcji. W razie niepowodzenia militarnego, Rzymianom pozostają rokowania i porozumienie, związane zazwyczaj z ustaleniem rocznych trybutów i subsydiów wypłacanych barbarzyńcom w zamian za powstrzymanie się od rabunku i zapewnienie $\mathrm{w}$ razie potrzeby wsparcia militarnego cesarstwu ${ }^{5}$. Jak widać pewien modus operandi plemion i przywódców gockich, przypisywany często dopiero przywódcom barbarzyńskim w IV w. był o wiele starszy niż przypuszczano. W zasadzie zarówno działania Terwingów na linii Dunaju, jak i późniejsze polityczne ewolucje Alaryka I, zmieniającego sojusze i obediencje bez mrugnięcia okiem, są jedynie ulepszoną formą prowadzenia polityki wobec imperium, dla którego zarówno Terwingowie (Wizygoci) w 1. poł., a Greutungowie (Ostrogoci) w 2. poł. V w. staną się nie tylko przedmiotem, ale w pewnych momentach wręcz podmiotem polityki tak zewnętrznej, jak i w dużo większym stopniu wewnętrznej.

Konstantyn Wielki (273-337, cesarz od 306) zmierzył się z Gotami z powodzeniem przynajmniej trzykrotnie $\left(324,332\right.$ i 336) ${ }^{6}$. Już wtedy myślano o wykorzystaniu militarnego potencjału Terwingów. Możliwe, że Licyniusz (265-325, cesarz od 308) w 324 r. próbował wykorzystać gockich sojuszników przeciw Konstantynowi Wielkiemu, a ten ostatni zawarł z nimi po 332 r. sojusz (foedus?) mający na celu wykorzystanie gockich kontyngentów dla zasilenia armii rzymskiej. Warto o tym wspomnieć tylko marginalnie, by ukazać, że

${ }^{4}$ Por. Berndt, Aktionsradien, s. 12, nota 16.

${ }^{5}$ Por. tamże, s. 13.

${ }^{6}$ Alexander Demandt (Geschichte der Spätantike. Das Römische Reich von Diocletian bis Justinian 282 - 565 n.Chr., 2. Auflage, München 2008, 54) jest przekonany, że przyjęcie nomen pro virtute „Gothicus” oraz budowa „kolumny gockiej” w Konstantynopolu nastapiły dopiero po przekroczeniu Dunaju w 336 r. i pokonaniu Gotów na ich własnym terytorium.

${ }^{7}$ Słowo „foedus” w nawiasie zostało celowo umieszczone w cudzysłowie, ponieważ mimo, że jest to pierwszy tak nazwany sojusz poświadczony źródłowo (H. Wolfram, Die Goten. Von den Anfängen bis zur Mitte des sechsten Jahrhunderts. Entwurf einer historischen Ethnographie, 3. Auflage, München - Wien 1990 71; J. Strzelczyk, Goci. Rzeczywistość i legenda, Warszawa 1984, 97; R. Scharf, Foederati. Von der völkerrechtlichen Kategorie zur byzantinischen Truppengattung, Tyche 4, Wien 2001, 19), to zgodnie z przyjmowanymi przez Herwiga Wolframa kryteriami za pierwszy foedus typowy dla tego typu zależności sojuszniczej w późnym Cesarstwie Rzymskim uznaje się traktat zawarty przez Teodozjusza Wielkiego z Gotami w roku 382 (Wolfram, Die Goten, s. 140). Różne wcześniejsze formy sojuszy między Rzymianami a barbarzyńcami, jak też różnorodne, stosowane w źródłach nazwy używane dla takich porozumień traktatowych obszerniej omawia Ralf Scharf (Foederati, s. 8-10). Wielu badaczy używa po prostu słowa foedus zgodnie z łacińskim znaczeniem na określenie wszelkich traktatów sojuszniczych, jednak wydaje się, że w literaturze dotyczącej późnego antyku słowo to stało się terminem fachowym i stosować się je powinno jedynie w przypadku traktatów zawieranych od końca IV w. zgodnie z przyjętym w foedus Teodozjańskim modelem. Po 
omówiona poniżej koncepcja „,zagospodarowania” sił gockich z korzyścią dla armii rzymskiej, która miała być szczególnie żywo dyskutowana na dworze cesarza Walensa, przed dopuszczeniem do przekroczenia Dunaju przez Gotów w 376 r., nie była niczym nowatorskim, a podobne rozwiązania były nie tylko brane pod uwagę, ale i praktykowane także w okresach wcześniejszych, choć Konstantyn Wielki nie brał pod uwagę dopuszczenia osiedlania się barbarzyńców na terenie imperium całym plemieniem, a jedynie w zamian za „dary” dla Gotów gwarantował sobie udział gockich oddziałów pomocniczych w działaniach swej armii.

Zanim cesarz Walens podją brzemienną w skutki decyzję o dopuszczeniu do osiedlenia się Gotów w prowincjach bałkańskich prowadził raczej politykę powstrzymywania ewentualnego napływu barbarzyńców przez Dunaj i usiłował zmusić do posłuchu plemiona gockie na lewym brzegu rzeki tak, by zniechęcić je do najazdów na tereny cesarstwa. Do wystapienia przeciw Terwingom (Wizygotom) skłoniły go wydarzenia związane z uzurpacją Prokopiusza (326-366, cesarz od 365). Uzurpator uzyskał wsparcie około trzytysięcznego korpusu wizygockiego, i choć korpus ten nie zdążył wziąć udziału w walkach przed upadkiem Prokopiusza ${ }^{8}$, to jednak rozgniewany Walens odciął wycofującym się Gotom drogę odwrotu i zagarnąwszy cały korpus w niewolę zmusił napastników do pozostania pod strażą na ziemiach cesarstwa. Przywódca Gotów wystąpił z żądaniem umożliwienia powrotu swoich internowanych wojowników, co miało być powodem pierwszej wojny gockiej prowadzonej przez Walensa9. Osiedlenie barbarzyńskich wojowników, niekoniecznie dobrowolnie przetrzymywanych na terenie rzymskim, nie było dla terenów obecnej północnej Bułgarii zjawiskiem nowym. Zazwyczaj starano się rozmieścić osiedleńców w niewielkich miejscowościach niedaleko od ważnych ośrodków, jednak konsekwentnie unikano osiedlania ich w miastach. Ulrich Wanke polemizując z Herwigiem Wolframem uważa, że fakt rozmieszczenia internowanych Gotów w osadach przy granicy wyklucza włączenie ich jako foederati do wojsk liniowych (comitatenses) ${ }^{10}$. Być może wspominani niżej

zawarciu sojuszu przez Konstantyna Wielkiego posiłki gockie wykorzystano na froncie perskim co najmniej trzykrotnie, por. G. Kampers, Geschichte der Westgoten, Paderborn 2008, 51.

${ }^{8}$ Por. Ammianus Marcellinus, Res gestae XXVI 10, 3, ed. É. Galletier, t. 5: Livres XXVI-XXVIII, Paris 1984, 94-95, thum. I. Lewandowski: Ammianus Marcellinus, Dzieje rzymskie, t. 2, Warszawa 2001, 49; Eunapius Sardianus, Fragmenta historica 37, ed. i tłum. w: Eunapios z Sardes, Zapiski historyczne. ІІTOPIKА ҮПОMNEMATA, [wydanie bilingwiczne], przekład, wstęp i objaśnienia A. Pająkowska-Bouallegui, Gdańsk 2013, 78. Zgodnie z częstą u historiografów wschodniorzymskich manierą Wizygoci kryją się u Eunapiosa pod nazwą Scytów.

${ }^{9}$ Por. Eunapius Sardianus, Fragmenta historica 37, ed. i tłum. Pająkowska-Bouallegui, s. 78; Zosimus, Historia Nova IV 10, 1, ed. L. Mendelssohn, Lipsiae 1887, Teubner, [reprint: Hildesheim 1963], 166, thum. H. Cichocka: Zosimos, Nowa historia, Warszawa 2012, 208.

${ }^{10}$ Por. U. Wanke, Die Gotenkriege des Valens. Studien zu Topographie und Chronologie im unteren Donauraum von 366 bis 378 n.Chr., Europäische Hochschulschriften III: Geschichte und ihre Hilfswissenschaften 412, Frankfurt am Main 1990, 76. 
Sweryd i Kolias, wodzowie wojsk gockich w służbie cesarskiej w 378 r., byli przywódcami przynajmniej części kontyngentu gockiego zaciągniętego przez Prokopiusza i internowanego przez Walensa ${ }^{11}$.

Wiosną $367 \mathrm{r}$. armia Walensa rozpoczęła działania militarne przeciw Gotom. Po zgrupowaniu wojsk w okolicach Daphne nad Dunajem siły cesarskie przekroczyły rzekę i rozpoczęły operację na terenach wroga ${ }^{12}$. Przebieg trwającej do 369 r. wojny gockiej Walensa (zwanej czasem pierwszą wojną gocką, dla odróżnienia od wydarzeń z lat 376-378/382) nie jest przedmiotem rozważań w tym artykule ${ }^{13}$, interesujące są natomiast działania pozamilitarne i warunki pokoju, kończącego tę fazę konfliktów. Oczywiście nieustająca obecność wojsk rzymskich pod dowództwem samego cesarza była dla Gotów nie tylko dużym zagrożeniem, ale i obciążeniem. Działania wojenne, połączone $\mathrm{z}$ embargiem handlowym doprowadziły do zachwiania dotychczasowego zaopatrzenia Gotów zarówno w produkty luksusowe, jak i w te najpilniej potrzebne. Braki w zaopatrzeniu musiały być wyjątkowo dokuczliwe. Od czasu porozumienia w Konstantynem Wielkim handel na pograniczu dunajskim rozwijał się pomyślnie i bez zakłóceń, a spore skarby monet bitych za panowania Konstancjusza II (317-361, cesarz od 337) świadczą o okresie prosperity $\mathrm{w}$ wymianie pomiędzy imperium a barbarzyńcami ${ }^{14}$. Wydaje się, że Walens świadomie zagrał także kartą ekonomiczną i możliwe, że właśnie niedostatki wynikające z praktycznie całkowitego powstrzymania handlu w większym stopniu przyczyniły się do osłabienia oporu Gotów niż prowadzone z przerwami działania wojenne. Ammianus Marcellinus (330-392) zgodnie z obowiązującą konwencją najpierw powiadamia, że u wrogów narastał strach przed cesarzem nieustannie pozostającym $\mathrm{w}$ rejonie walk, ale zaraz potem jednoznacznie stwierdza, że skrajny deficyt towarów związany z embargiem handlowym tak dokuczał Gotom, że słali nieustannie posłów z prośbą o pokój i przebaczenie ${ }^{15}$. Ostatecznie rokowania pokojowe podjęto na specjalnie w tym celu skonstruowanej tratwie na Dunaju w okolicach Noviodunum, co miało być związane z przysięgą złożoną niegdyś przez Atanaryka, wodza Gotów, że nigdy

${ }^{11}$ Obydwaj wodzowie o których wcześniejszych losach, czy też datach życia nic nam nie wiadomo wspomniani są przez Ammiana Marcellina (Res gestae XXXI 6, 1-4, ed. É. Galletier, t. 4: Livres XXIII-XXV, Paris 1987, 117-118, thum. Lewandowski, t. 2, s. 235-236) w kontekście wydarzeń wielkiego buntu Gotów w 378 roku.

${ }^{12}$ Por. tamże XXVII 5, 2, ed. Galletier, t. 5, s. 116, thum. Lewandowski, t. 2, s. 67-68.

${ }^{13}$ Dokładne opracowanie przebiegu działań wojennych 367-369 r. wraz z ciekawymi hipotezami dotyczącymi umiejscowienia poszczególnych faz operacji zainteresowany Czytelnik znajdzie w ciągle aktualnej monografii Ulricha Wanke (Die Gotenkriege, s. 79nn), a w formie skróconej w pracy Herwiga Wolframa (Die Goten, s. 76nn).

${ }^{14}$ Por. Kampers, Geschichte der Westgoten, s. 51.

${ }^{15}$ Por. Ammianus Marcellinus, Res gestae XXVII 5, 7, ed. Galletier, t. 5, s. 117: „Dein quod commerciis uetitis ultima necessariorum inopia barbari stringebantur adeo, ut legatos supplices saepe mittentes, uenialem poscerent pacem". 
nie dotknie nogą rzymskiej ziemi ${ }^{16}$. Na razie udało się Walensowi osiagnnać korzystne warunki. Rzymianie utrzymali swoją dotychczasową prymarną pozycję w stosunkach gocko-rzymskich, a więc utrzymali status quo, natomiast Wizygoci musieli zrezygnować z przeprawiania się na brzeg rzymski i zobowiązać się do poszanowania i nienaruszania granic imperium ${ }^{17}$. Przywrócono też handel, ale ograniczono znacznie ilość miejsc wymiany. Być może obustronnie lub tylko ze strony Gotów dano zakładników.

W przytoczonych faktach dostrzec można dwie podstawowe linie polityki dworu cesarskiego wobec Gotów widoczne w pierwszej fazie omawianego okresu. Po pierwsze dopuszcza się możliwość korzystania z gockich oddziałów posiłkowych i w warunkach pokoju nie przeszkadza się w rozwoju kontaktów handlowych. Po drugie jednak stałą i niezłomną jak na razie zasadą jest niedopuszczanie do przeprawiania się barbarzyńców większymi grupami poza graniczny Dunaj, a już pod żadnym pozorem do osiedlania się większych grup na terytorium rzymskim. Jeżeli już dochodzi do osiedlenia, tak jak w przypadku domniemanego traktowania Gotów z kontyngentu zwerbowanego przez Prokopiusza, to nie jest to osadnictwo z rodzinami, lecz osadnictwo możliwie rozproszone i w żadnym wypadku nie obejmujące miast. Przy okazji możemy przekonać się, że na razie dwór rzymski nie wykazuje zainteresowania bliższym poznaniem kultury, sposobu życia i mentalności Terwingów, czy też Gotów w ogóle. Wywiad cesarski interesowały zapewne wyłącznie dane potrzebne do operacji wojskowych. Natomiast ze strony Gotów, a przynajmniej ze strony najwyższych warstw ich społeczności, występuje pewne zainteresowanie i rozeznanie w zakresie praktyki politycznej Rzymian. Dowodzi tego krępująca sytuacja na początku rokowań, kiedy to Walens zwracając się do Ata-

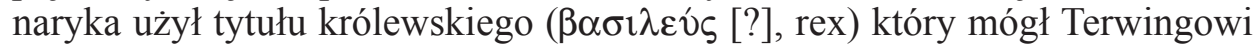
kojarzyć się z gockim * reiks, co dla Atanaryka mogło oznaczać sprowadzenie go do rangi jednego z gockich wodzów i być obraźliwe. Aby uniknąć konfliktu u początku rokowań zręcznie wybrnął z sytuacji, prosząc, by cesarz nazywał go raczej sędzią ( związany z roztropnością, a nie jedynie posiadaniem władzy ${ }^{18}$. Możliwe jest jednak, że barbarzyńca zrozumiał, iż użycie tytułu królewskiego stawia go

${ }^{16}$ Por. tamże XXVII 5, 9, ed. Galletier, t. 5, s. 118, thum. Lewandowski, t. 2, s. 69-70. W relacji znajduje się też wyjaśnienie, że przeprawa cesarza na drugi brzeg byłaby umniejszeniem dla jego majestatu, dlatego zdecydowano się rokować na środku rzeki.

${ }^{17}$ Por. Zosimus, Historia Nova IV 11, 4, ed. Mendelssohn, s. 168, thum. Cichocka, s. 209. Ammianus Marcellinus (Res gestae XXVII 5, 9, ed. Galletier, t. 5, s. 118, thum. Lewandowski, t. 2, s. 69-70) mówi tylko o zawarciu pokoju bez określania warunków, natomiast Eunapios z Sardes (Fragmenta historica 37, ed. i thum. Pająkowska-Bouallegui, s. 79) informuje jedynie, że wojna scytyjska została doprowadzona do spokojnego i szczęśliwego końca.

${ }^{18}$ Themistios, Orationes, übers. von H. Leppin - W. Portmann: Themistios, Staatsreden, Bibliothek der Griechischen Literatur 46, Stuttgart 1998, 191. Także Ammianus Marcellinus (Res gestae XXVII 5, 9, ed. Galletier, t. 5, s. 118 tłum. Lewandowski, t. 2, s. 70) informuje, że na tratwę na środku Dunaju przewieziono principem gentisque iudicem. O różnych aspektach władzy Wizy- 
niżej od rokującego z nim Augusta Romanorum i zręcznie wywinął się z proceduralnej pułapki. Jak widać Walens nie posiadał rozeznania w strukturze społeczeństwa gockiego, a z kolei Atanaryk wykazał się i wiedzą i roztropnością, którą sobie przypisywał. Warto przy tej okazji zwrócić uwagę na pewną niekonsekwencję w źródłach wschodniorzymskich, które wykazują wzajemną zależność. Chodzi o relacje Eunapiosa z Sardes (345/349? - 404) i Zosimosa (425? - 518?) dotyczące tego samego wydarzenia, czyli żądania przywódcy Gotów, aby wydano internowanych przez Walensa wojowników posłanych z pomocą uzurpatorowi Prokopiuszowi. Eunapios używa jednoznacznie tytułu królewskiego, ó $\Sigma \kappa v \theta \omega \hat{v} \beta \alpha \sigma \imath \lambda \varepsilon v ́ s$, natomiast późniejszy Zosimos ogra-

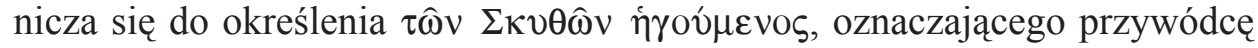
plemienia czy wodza, które niewątpliwie oznacza godność niższą niż ta, którą w czasach twórczości Zosimosa zwykło się wiązać z tytułem $\beta \alpha \sigma \imath \lambda \varepsilon v ́ \varsigma^{19}$. Dlaczego piszący o wiek wcześniej Eunapios bez problemu używa tytułu królewskiego, a wiek późniejszy przekaz Zosimosa, zależny od Eunapiosa, umniejsza rangę władcy Gotów (Scytów, zgodnie z konwencją wschodniorzymską)? $\mathrm{Czy}$ jest to wynikiem lepszego rozeznania w różnicach struktur społecznych Gotów i Rzymian, czy może raczej aprecjacji zakresu znaczeniowego tytułu $\beta \alpha \sigma \imath \lambda \varepsilon v ́ s$ za czasów Zosimosa? Pamiętajmy, że ten ostatni tworzył w okresie, gdy przynajmniej na Zachodzie istnieli już suwerenni reges barbarzyńscy od czasów panowania Gejzeryka (368/370? - 477, król od 428) czy Euryka (410/415? - 484, król od 466), którzy uważali się za władców równorzędnych cesarzom. Piszący nieco później Prokopiusz z Cezarei (490/507? - 561?) stara się unikać tytułowania suwerennych władców (np. Wandalów), a jedynie podając treść listu Tzazona $(† 533)$ do jego brata, króla Wandalów Gelimera (ok. 480 - po 534, król od 530), pozwala sobie na użycie w cytacie tytułu

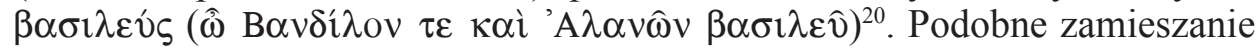
w tytułowaniu widoczne jest szczególnie w przypadku Alaryka ${ }^{21}$. Jak widać, jeszcze w siódmej i ósmej dekadzie IV w. Wizygoci, czy też Goci w ogóle zajmują w myśli politycznej i w praktycznym jej zastosowaniu miejsce marginalne, jednego z wielu ludów barbarzyńskich, którego znajomość ogranicza się do powierzchownych stereotypów, a użyteczność polityczna sprowadza się jedynie do okazjonalnego korzystania z kilkutysięcznych kontyngentów

gockich „sędziów” zob. H. Wolfram, Gotische Studien. Volk und Herrschaft im frühen Mittelalter, München 2005, 110nn.

${ }^{19}$ Eunapius Sardianus, Fragmenta historica 37, ed. i thum. Pająkowska-Bouallegui, s. 78; Zosimus, Historia Nova IV 10, 1, ed. Mendelssohn, s. 166, thum. Cichocka, s. 208. Autorzy zachodniorzymscy, posługujący się łaciną nie mieli takich problemów, rozróżnienie pomiędzy rex, a augustus lub caesar było jasne, jednoznaczne i ściśle przypisane do struktur społeczeństwa barbarzyńskiego i rzymskiego.

${ }^{20}$ Procopius Caesariensis, De bellis III 24, 3, rec. J. Havry, addenda et corrigenda adiecit G. Wirth: Procopius, Opera omnia, vol. 1, Lipsiae 1962, 410, thum. D. Brodka: Prokopiusz z Cezarei, Historia wojen, t. 1: Wojny z Gotami, Źródła Historyczne, Kraków 2015, 269.

${ }^{21}$ Por. nota 54. 
pomocniczych. Brak rozeznania i wyczucia mentalności barbarzyńców miał W przyszłości kosztować Rzymian o wiele więcej niż dyplomatyczne niezręczności, choć w okresie późniejszym, szczególnie w trzeciej fazie omawianego okresu pobytu Wizygotów na Bałkanach, zdarzali się wśród polityków cesarskich ludzie umiejący ze znajomości obyczajów barbarzyńców ciągnąć korzyści.

Ammianus Marcellinus pisząc ex post bardzo pozytywnie ocenił zawarty w 369 r. pokój, chwaląc władcę Rzymian, który „,nie miał wprawdzie doświadczenia w tych sprawach, ale był - jak dotąd - bardzo sprawiedliwym obserwatorem wydarzeń" 22 . Zaraz potem jednak z goryczą przypomina, że ulegając później pochlebcom dworskim sprowadził na państwo rzymskie straszliwe szkody godne wiecznego opłakiwania. Nawiązuje w ten sposób do zezwolenia na osiedlenie się Gotów na Bałkanach i następującą potem porażkę w bitwie pod Adrianopolem 9 sierpnia 378 roku. Podobnie jak w przypadku wojny 367369 nie jest konieczne dokładne opisywanie w porządku chronologicznym znanych ze źródeł i opracowań wydarzeń związanych z osiedleniem się Gotów na Bałkanach, chodzi jedynie o prześledzenie tych wydarzeń i opinii, które mogą być pomocne w określeniu miejsca jakie zajmowali wtedy Goci w polityce dworów cesarskich (w zasadzie głównie dworu w Konstantynopolu).

W zamieszaniu wywołanym atakiem Hunów na krymskie „państwo” Ostrogotów i związaną z tym wydarzeniem migracją wytworzyła się sytuacja, jakiej jeszcze dotąd nie odnotowały dzieje Imperium Romanum. Po raz pierwszy na granicy cesarstwa pojawiła się fala potencjalnych imigrantów, a nie zdobywców myślących wyłącznie o rabunku i ewentualnych zdobyczach terytorialnych. Oczekiwania Terwingów i połączonych z nimi grup Greutungów były inne. Przede wszystkim oczekiwali schronienia w granicach cesarstwa, przerażeni brutalnością i zupełnie nieznanymi im metodami prowadzenia walki, które przyniósł ze sobą do ich względnie stabilnego świata najazd Hunów ${ }^{23}$. Jeżeli wierzyć Ammianowi Marcellinowi przygotowania obronne podjęte przez Atanaryka nie zdołały zapewnić skutecznej obrony przed mobilnymi oddziałami huńskiej jazdy ${ }^{24}$. Nie bez znaczenia musiały być też skutki ruchów migracyjnych za północną granicą terenów bałkańskich. Pierwszym i najważniejszym było zachwianie $\mathrm{i}$ tak kruchej równowagi w zakresie aprowizacji. Zasoby żywności, których uzupełnianie poprzez handel z cesarstwem było, jak wykazało embargo handlowe z lat 367-369, konieczne, nie mogły wystarczyć

${ }^{22}$ Ammianus Marcellinus, Res gestae XXVII 5, 9, ed. Galletier, t. 5, s. 118, thum. Lewandowski, t. 2 , s. 69 .

${ }^{23} \mathrm{O}$ początkach wielkiej migracji wywołanych najazdem Hunów: Eunapius Sardianus, Fragmenta historica 42, ed. i thum. Pająkowska-Bouallegui, s. 84 i 86; Zosimus, Historia Nova IV 20, 3-5, ed. Mendelssohn, s. 174-175, thum. Cichocka, s. 217-218; Ammianus Marcellinus, Res gestae XXXI 3, 1-3, ed. É. Galletier, t. 6: Livres XXIX-XXXI, Paris 1999, 105-106, thum. Lewandowski, t. 2, s. 225-226.

${ }^{24}$ Por. Ammianus Marcellinus, Res gestae XXXI 3, 4-8, ed. Galletier, t. 6, s. 106nn, thum. Lewandowski, t. 2, s. 226-227. 
wobec wzrostu liczby ludności stymulowanej wymuszoną migracją. Nie wiemy dokładnie jak wielka była ta liczba. Źródła mówią jedynie o wielkiej masie barbarzyńców i tylko u Eunapiosa spotykamy konkretną, choć oczywiście bardzo okragłą liczbę 200 tys. wojowników (zdatnych do walki ludzi w kwiecie wieku) ocalonych z pogromu i chcących przekroczyć Dunajes. Nie wiadomo czy chodzi tu o samych Terwingów, ponieważ mowa jedynie o ocalałych spod huńskiego miecza, jednak zapewne Eunapios miał na myśli wszystkich Gotów, a więc także niedobitki Greutungów włączył do podanej liczby. Z pełną świadomością wszelkich zastrzeżeń odnośnie podawanej w źródłach antycznych liczebności ludów spróbujmy jednak przyjąć, że Eunapios dysponował w miarę wiarygodnymi danymi. Podana liczba dotyczyła wojowników, a więc stosując przyjęte powszechnie przeliczniki stosunku liczebności wojowników do reszty ludu jako 1:4 osiagniemy ogólną liczbę ludu sięgającą prawie jednego miliona, co jest wartością niespotykaną w dotychczasowych konfliktach granicznych między barbarzyńcami a Rzymianami i zapewne zawyżoną. Niezależnie od watpliwości co do prawdziwości omawianego przekazu można, idąc za zgodnym świadectwem źródeł, uznać na pewno jedno: uciekinierów - potencjalnych imigrantów - było po prostu bardzo wielu, tak wielu, że było to zupełnie nowe i zaskakujące dla dworu konstantynopolitańskiego zjawisko. O szybkim wyczerpywaniu się zasobów żywności za Dunajem informuje Ammianus Marcellinus, pisząc, że większa część ludności wycieńczona brakiem środków do życia opuściła Atanaryka. Wspomina też, że szukającym wyjścia z trudnej sytuacji Gotom ziemie Tracji wydawały się atrakcyjne jako niezwykle żyzne i oddzielone od budzących grozę Hunów wodami Dunaju ${ }^{26}$. Określone w tej relacji dwa najważniejsze dla Gotów priorytety, bezpieczeństwo i zapewnienie ludowi niezbędnych środków do życia, pozostaną na kilka dziesięcioleci podstawową linią polityki i podstawowymi oczekiwania wodzów gockich wobec rządów obydwóch części cesarstwa.

Pojawienie się wielkiej masy uciekinierów i ludzi chcących zapewnić sobie dostatnią egzystencję na granicy dunajskiej stało się wielkim wyzwaniem dla cesarza Walensa, który jak się wydaje starał się rozwiązać problem jak najlepiej. Dokładniejsze naświetlenie toku rozumowania cesarza i kręgów dworskich utrudnia nieoceniony w innych przypadkach Ammianus Marcellinus, którego pełne goryczy komentarze, pisane już po clades Hadrianopolitana, od samego początku naznaczają cesarza piętnem nieudolności i lekkomyślności, a w najlepszym razie ślepego zadufania podsycanego pochlebstwami dworaków. Mimo to warto poszukać w jego relacji nieco informacji na temat oczekiwań dworu cesarskiego związanych z napływem gockich przybyszów. Przynajmniej część ludzi z dworu Walensa widziała w przyjęciu proszących o schronienie i wyżywienie Gotów konkretne korzyści dla imperium. Liczono

\footnotetext{
${ }^{25}$ Por. Eunapius Sardianus, Fragmenta historica 42, ed. i tłum. Pająkowska-Bouallegui, s. 84 i 86.

${ }^{26}$ Ammianus Marcellinus, Res gestae XXXI 3, 8, ed. Galletier, t. 6, s. 105-106, thum. Lewandowski, t. 2, s. 227.
} 
przede wszystkim na wzmocnienie sił armii cesarskiej. Jak pisze Ammianus Marcellinus, doświadczeni pochlebcy sławić mieli szczęśliwy los władcy, który darował Rzymowi nowe, liczne kontyngenty rekrutów. Wskazywali na podwójną korzyść, bowiem z jednej strony armia cesarska połączona z siłami plemion gockich stanowić będzie siłę ogromną i niezwyciężoną, z drugiej zaś skarbiec cesarski zaoszczędzi wielkie sumy, których nie będzie trzeba wydawać na kosztowne zaciągi, tak więc podatki wnoszone przez poszczególne prowincje na potrzeby militarne można będzie wykorzystać w innym celu ${ }^{27}$. Mimo że z relacji tej wyziera typowa dla Ammiana gorycz i niechęć do dworskiej kamaryli, to jednak nie sposób orzec, czy były to głosy wyłącznie głupich i zaślepionych chęcią zysku i pochlebiania cesarzowi dworaków. Logicznie myśląc plan przyjęcia Gotów i wykorzystania ich militarnie nie był wszak niczym oryginalnym, ponieważ już wcześniej osadzano barbarzyńców jako laeti i gentiles dla ochrony niewielkich odcinków granic, jak widać choćby $\mathrm{z}$ tekstu tego artykułu, i bez większych oporów sięgano też $\mathrm{w}$ razie potrzeby po większe kontyngenty. Różnica była jedynie w ilości. Tym razem nad granicą znajdowały się ogromne masy uciekających przed Hunami, czy też przed niedostatkiem żywności na lewym, barbarzyńskim brzegu Dunaju. Odmiennie też niż w okresach wcześniejszych wojownikom towarzyszyły całe rodziny. Tego kręgi dworskie nie wzięły pod uwagę. Z pozycji polityka wysokiej rangi problemy logistyczne czy aprowizacyjne, oczywiste dla każdego trybuna a nawet dla prostego żołnierza, nie istniały. Widziano jedynie spodziewaną korzyść i dołożono wszelkich starań, aby plan przyjęcia uciekinierów w pełni zrealizować, co Ammianus Marcellinus opatrzył kąśliwą uwagą, że urzędnicy cesarscy, posłani, by zorganizować przeprawę Gotów, uczynili wszystko, aby na drugim brzegu nie pozostał nikt z tych, którzy później niszczyli cesarstwo, nawet jeżeli tknięty był śmiertelną chorobą ${ }^{28}$. Złośliwość historyka-żołnierza jest w pełni zrozumiała w świetle tego, co później miał widzieć i opisać. Jednak w momencie przeprawy jedynie bardzo dalekowzroczni mogli przewidzieć wypadki następnych kilku lat. Można zgodzić się z opinią Gerda Kampersa, że tak naprawdę to obydwie strony, tak rzymska, jak i barbarzyńska nie miały wielkiego wyboru i sytuacja była raczej bez wyjścia. Przyjęcie Gotów i wykorzystanie ich potencjału militarnego było nie tylko szansą odniesienia korzyści, o których mówili dworscy pochlebcy, ale było także praktycznie jedyną szansą na uniknięcie militarnego konfliktu ze zdesperowanymi do granic możliwości barbarzyńcami. $Z$ kolei dla Gotów przyjęcie proponowanych zasad było jedyną możliwością skorzystania z zasobów żywnościowych cesarstwa, które w razie gdyby przerwali granicę siłą w większej części pozostałyby poza ich zasięgiem ${ }^{29}$. Goci nie mieli drogi odwrotu i w razie odmowy

\footnotetext{
${ }^{27}$ Por. tamże XXXI 4, 4, ed. Galletier, t. 6, s. 109, thum. Lewandowski, t. 2, s. 227-228.

${ }^{28}$ Por. tamże.

${ }^{29}$ Por. Kampers, Geschichte der Westgoten, s. 88-89.
} 
i tak podjęliby próbę sforsowania Dunaju ${ }^{30}$. Pamiętać należy o podanej przez Eunapiosa liczbie 200 tys. wojowników. Nawet jeżeli była to spora przesada, to zachodzi pytanie, czy cesarz był w stanie w krótkim czasie zgromadzić na zagrożonej granicy wystarczającą liczbę wojsk, by odeprzeć inwazję. W świetle tych przemyśleń rady udzielone Walensowi przez dwór i przyjęte przez cesarza nie wydają się zupełnie pozbawione sensu.

Gdzie więc popełniono błąd? Wydaje się, że fałszywie oceniono rozmiar migracji i nie dopełniono podstawowych zasad bezpieczeństwa. Nie oszacowano należycie liczby przeprawianych przez Dunaj barbarzyńców i nie kontrolowano stanu uzbrojenia przybywających ${ }^{31}$. Michael Kulikowski uważa, że było to sprzeczne z zasadą rozbrajania barbarzyńców wpuszczanych do cesarstwa i dozbrajania dopiero, gdy weszli w struktury wojsk pomocniczych ${ }^{32}$. Zapewne ma słuszność, choć z kolei Gerd Kampers uważa, że cesarz świadomie zezwolił na przeprawienie nierozbrojonych barbarzyńców i na ich zwarte osadnictwo $^{33}$. Kolejnym sygnalizowanym przez autorów źródeł problemem była korupcja wśród urzędników, którzy zdaniem Eunapiosa i Zosimosa mieli polecenie liczenia i rozbrajania przeprawiających się grup barbarzyńców, jednak zaniechali swoich obowiązków poszukując łatwego zysku i rozpusty. I Eunapios i Zosimos wspominają o wybieraniu sobie spośród przeprawianych grup gockich pięknych chłopców i dziewcząt do rozpusty, jak też o poszukiwaniu różnego rodzaju wartościowych lub pięknych przedmiotów, które sobie przywłaszczano. Możliwe, że chodziło nie tylko o rozpustę, ale o poszukiwanie atrakcyjnych niewolników i niewolnic. Tak więc przynajmniej część odpowiedzialnych za przeprawę usiłowała zyskać korzyści materialne kosztem uchodźców. Jak widać wszelkie możliwe patologiczne zachowania wynikające z trudnej sytuacji przyjmowanych imigrantów bardzo przypominały pewien ,pakiet” nieprawości towarzyszący wszelkim migracjom $\mathrm{w}$ historii (wykorzystywanie słabszych, pobieranie haraczu, zmuszanie do prostytucji, handel żywym towarem). Ammianus Marcellinus za szczególny przykład chciwości i podłości uważa postępowanie kierujących osiedlaniem Gotów w Tracji: Lupicynusa komesa Tracji i Maksymusa duksa lokalnych wojsk.

${ }^{30} \mathrm{O}$ tym, że próby forsowania rzeki bez zgody Rzymian były podejmowane zaświadcza Eunapios (Fragmenta historica 42, ed. i thum. Pająkowska-Bouallegui, s. 86), dodając, że Rzymianie pobili intruzów, jednak dowódcy którzy ich powstrzymali, zostali (co ciekawe) ukarani za swój czyn. Nie wiadomo niestety, czy ten wtręt opisuje rzeczywiste wydarzenia, czy też na kanwie informacji o jakichś powstrzymanych próbach przeprawy Eunapios buduje obraz zbrodniczej niekonsekwencji i krótkowzroczności władz cesarskich.

${ }^{31}$ Por. Ammian Marcellinus, Res gestae XXXI 4, 6, ed. Galletier, t. 6, s. 110, thum. Lewandowski, t. 2, s. 228; Eunapius Sardianus, Fragmenta historica 42, ed. i tłum. Pająkowska-Bouallegui, s. 86; Zosimus, Historia Nova IV 20, 6, ed. Mendelssohn, s. 175, thum. Cichocka, s. 218. Zob. też H. Wolfram, Die Goten, s. 127.

${ }^{32}$ Por. M. Kulikowski, Wojny Rzymu z Gotami od III wieku do Alaryka, tłum. Ł. Różycki, Oświęcim 2015, 104.

${ }^{33}$ Por. Kampers, Geschichte der Westgoten, s. 88. 
Obydwaj wykorzystać mieli trudne położenie Gotów w szczególnie upokarzający i podły sposób. Zamiast dostaw żywności dostarczali podobno głodnym wojownikom psie mięso i chleb, wymieniając niewielkie ilości tej żywności za niewolników. Ofiarami tych podłych interesów padać mieli nawet członkowie rodzin naczelników, oddawani w niewolę za żywnośćc ${ }^{34}$. Autorzy źródeł bardzo surowo oceniają postępowanie Lupicynusa i Maksymusa, którzy nie chcieli udostępnić zdesperowanym Gotom zapasów żywności, które przecież musiały być zapewnione przybyszom. Jeżeli jednak podjąć próbę chłodnej oceny sytuacji, to może na całość sprawy można spojrzeć inaczej, choć rzecz jasna nikt nie będzie starał się bronić reputacji obydwóch cesarskich urzędników z Tracji, na których niekorzyść świadczą także i inne czyny. Przesadna chciwość nie da się obronić, ale może za skapym wydzielaniem racji żywnościowych Gotom krył się jakiś głębszy zamysł administracji cesarskiej? Wszelkie informacje źródeł świadczą o tym, że w bardzo wczesnej fazie przeprawy Gotów przez Dunaj urzędnicy cesarscy całkowicie utracili kontrolę nad ogromną masą imigrantów. Nie dokonano zliczenia ani rozbrojenia przybywających, a więc może skąpe zaopatrywanie w żywność i utrzymywanie wojowników $\mathrm{i}$ ich rodzin w stanie permanentnej zależności aprowizacyjnej od administracji rzymskiej miało być narzędziem odzyskania przynajmniej w części kontroli nad biegiem wypadków. Do takiej refleksji skłania niewielka uwaga Ammiana Marcellina, który opisał podły plan zgładzenia wodzów Wizygotów na uczcie w Marcjanopolu podjęty przez Lupicynusa. Przy okazji historyk pisze, że pod murami miasta pozostawały tłumy Gotów i ,ludzie ci posłuszni przecież naszej władzy i przystający na nią, uparcie błagali, by pozwolono im wejść do miasta w celu zaopatrzenia się w niezbędną żywność" ${ }^{35}$. Zatem przypuszczać można, że gdyby żywności tej użyczono bardziej szczodrze, to Goci byliby gotowi do kompromisu. W miejsce kompromisu nastąpił bunt, na czele którego stanęli Fritigern († ok. 380) i Alawiw († 378).

Innym powodem ograniczenia dostaw żywności mogła być też obawa o własne zasoby, które wobec wielkiej liczby imigrantów musiały się władzom poszczególnych miast wydawać niezwykle małe. Nieporozumienie na tym tle spowodowało przejście służących dotychczas cesarzowi Sweryda i Koliasa wraz z ich oddziałami na stronę buntu. Obydwaj wodzowie goccy w służbie rzymskiej, którzy stacjonowali pod Adrianopolem, otrzymali rozkaz wymarszu w kierunku Hellespontu. Kiedy, jak pisze Ammian, „bez żadnej arogancji” poprosili władze miasta o zaopatrzenie na drogę, te uzbroiwszy mieszkańców stawiły na własną rękę zbrojny opór. Jak łatwo było przewidzieć regularne

${ }^{34}$ Por. Ammianus Marcellinus, Res gestae XXXI 4, 9-11, ed. Galletier, t. 6, s. 110-111, thum. Lewandowski, t. 2, s. 229-230; Iordanes, Getica 134-135, ed. Th. Mommsen, MGH Auctores Antiquissimi V/1, Berolini 1882, 93, thum. E. Zwolski: Kasjodor i Jordanes. Historia gocka czyli scytyjska Europa, Rozprawy Wydziału Historyczno-Filologicznego 49, Lublin 1984, 114.

${ }^{35}$ Ammianus Marcellinus, Res gestae XXXI 5, 5, ed. Galletier, t. 6, s. 113, tłum. Lewandowski, t. 2, s. 231 . 
oddziały gockie bez trudu poradziły sobie z miejskim pospolitym ruszeniem, zadając mieszkańcom Adrianopola poważne straty i oburzone biegiem wypadków przeszły na stronę zbuntowanych Gotów Fritigerna i Alawiwa. W sytuacji rozszerzającego się buntu Lupicynus starał się jeszcze zapanować nad sytuacją próbując usunąć przywódców. W czasie uczty w Marcjanopolu starał się doprowadzić do zamordowania Fritigerna i Alawiwa, jednak Fritigernowi udało się wymknąć niebezpieczeństwu ${ }^{36}$. Nie jest wykluczone, że zabity w Marcjanopolu Alawiw był ojcem Alaryka I, co w przyszłości mogło w znacznym stopniu wpływać na stosunek pierwszego króla Wizygotów do władz rzymskich ${ }^{37}$.

Zagrożenie gockie zostało w pełni docenione zarówno na dworze wschodnim, jak i zachodnim. Walens porzucając wszelkie aktualne działania przeprowadził szybką mobilizację, która pozwoliła mu na wymarsz z Konstantynopola na czele 30-40 tysięcznej armii ${ }^{38}$. Równocześnie zaalarmowany przez stryja podążał na pomoc Walensowi jego bratanek, cesarz Zachodu, Gracjan (359-383, cesarz od 367). Armia Zachodu włączyła się do działań z pewnym opóźnieniem, spowodowanym niepokojami na granicy Renu wywołanymi przez Alamanów ${ }^{39}$. Problem buntu potraktowano poważnie. Walens, mimo (a może właśnie z powodu) sukcesów nowo mianowanego wodza cesarskiego, Sebastiana $(† 378)^{40}$, zdecydował się objąć dowództwo osobiście. Znowu zawiodły służby zwiadowcze, które zupełnie fałszywie oceniły liczebność zbuntowanych Gotów, stacjonujących pod dowództwem Fritigerna w okolicy Adrianopola przy stanicy pocztowej Nike, na zaledwie 10 tys. wojowników. W otoczeniu cesarza ponownie doszło do sporów między wojskowymi a cywilnymi doradcami. Część wyższych rangą żołnierzy radziła czekać na przybycie wojsk Gracjana, natomiast cywilni doradcy i kilku dowódców uważali, że Walens nie powinien się dzielić z bratankiem sławą pogromcy Gotów. Niezależnie od poglądu na to, czy czekać na armię Zachodu, czy też nie, zupełnie fałszywe rozeznanie w sytuacji powodowało, że nikt w otoczeniu Walensa nie wątpił w pewne zwycięstwo ${ }^{41}$.

Jak powszechnie wiadomo 9 sierpnia 378 r. pewne zwycięstwo odniosła strona gocka. Pomijając opis bitwy, który nie jest przedmiotem artykułu,

${ }^{36}$ Por. tamże XXXI 5, 5-8, ed. Galletier, t. 6, s. 113-114, tłum. Lewandowski, t. 2, s. 231-232.

${ }^{37}$ Por. M. Wilczyński, Germanie w stużbie zachodniorzymskiej w Vw. n.e. Studium historyczno-prosopograficzne, Prace Monograficzne - Akademia Pedagogiczna im. Komisji Edukacji Narodowej w Krakowie 299, Kraków 2001, 116.

${ }^{38}$ Oszacowanie za: Kulikowski, Wojny Rzymu z Gotami, s. 111.

${ }^{39}$ Por. Ammianus Marcellinus, Res gestae XXXI 10, 1-10, ed. Galletier, t. 6, s. 130nn, thum. Lewandowski, t. 2, s. 245-246.

${ }^{40}$ Por. tamże XXXI 11, 1-5, ed. Galletier, t. 6, s. 136-137; Eunapius Sardianus, Fragmenta historica 44, 3-4, ed. i tłum. Pająkowska-Bouallegui, s. 92 i 94, Sebastian, doświadczony wódz przybyły z Zachodu został mianowany prawdopodobnie do rangi magister peditum. Na temat jego działań patrz M. Speidel, Sebastian's Strike Force at Adrianople, „Klio” 78 (1996) nr 2, 434-437.

${ }^{41}$ Por. Ammianus Marcellinus, Res gestae XXXI 12, 8-9, ed. Galletier, t. 6, s. 140, thum. Lewandowski, t. 2, s. 253. 
można jedynie raz jeszcze wskazać na popełnione pod wpływem dworskich doradców błędy. Walens nie czekał na posiłki prowadzone przez Gracjana i tak w wigilię bitwy, jak i w samym jej dniu dał się wciagnąć w negocjacje z wysłannikami Fritigerna. Mogło to być wynikiem niewłaściwej oceny wroga i wzmocnionego jeszcze argumentami wspomnianych przez Ammiana Marcellina „pochlebców” fałszywego przekonania o słabości barbarzyńców i niezwyciężonej potędze cesarza. Fritigern z łatwością oszukał Walensa, mamiąc go kolejnymi próbami rokowań i odsuwając moment starcia, by zmęczona przemarszem ku obozowi Gotów armia rzymska dodatkowo osłabła w upale, potęgowanym jeszcze sztucznie przez palone przez barbarzyńców ogniska. Uleganie wygodnym propagandowym stereotypom (barbarzyńcy winni błagać imperatora o łaskę), danie posłuchu cywilnym doradcom dworskim i zadufanie kosztowały Walensa życie, a Rzymian kryzys, którego skutków mimo wszelkich podejmowanych później prób nie udało się odwrócić.

Szok adrianopolitańskiej klęski był ogromny. Wspomniane powyżej skutki sprawiły diametralną zmianę optyki w postrzeganiu stosunków gocko-rzymskich. Słuszne jest zdanie, że do 378 r. historię Gotów w rejonie Bałkanów kształtowało w dużej mierze cesarstwo, a plemię to było jednym $\mathrm{z}$ wielu plemion barbarzyńskich. Po bitwie Goci stali się stałym i dominującym elementem w polityce rzymskiej, już nie przedmiotem a podmiotem działań i idei politycznych, co więcej, niespełna 20 lat po Adrianopolu byli czynnikiem wpływającym w sposób zdecydowany na politykę dworów wschodnio- i zachodniorzymskiego ${ }^{42}$. Rozwiązanie problemu gockiego, powierzone przez Gracjana Teodozjuszowi I nazwanemu przez potomnych Wielkim (347-395, cesarz od 379), nie mogło już polegać na prostym wyparciu Gotów z powrotem poza granice cesarstwa. Po odniesieniu kilku sukcesów i poskromieniu rabunków barbarzyńców w Tracji, a nawet w pobliżu Konstantynopola, Teodozjusz I powrócił w zasadzie do punktu wyjścia, czyli do problemu osiedlenia Wizygotów w granicach cesarstwa w zamian za służbę na jego rzecz. Różnica polegała jednak na tym, że doświadczony wódz zdawał sobie sprawę z potencjalnych zagrożeń W o wiele większym stopniu niż Walens. Nowa praktyka polityczna wprowadzona przez Teodozjusza opierała się na zasadzie lepszego poznawania barbarzyńców i ich mentalności, co pozwalało na wykonywanie pewnych gestów wzmagających szacunek wobec Teodozjusza, i doprowadziło w konsekwencji do tego, że postrzegany on był przez Wizygotów nie tylko jako cesarz rzymski, ale niemalże jako * Diudans - najwyższy naczelnik i autorytet plemienia, amator pacis generisque Gothorum ${ }^{43}$. Do elementów tej polityki należało ostentacyjnie przyjazne przyjęcie w Konstantynopolu Atanaryka, wygnanego z jego ziem przez Fritigerna i uczczenie zmarłego wkrótce „sędziego" Wizygotów wspaniałym państwowym pogrzebem z osobistym udziałem cesarza ${ }^{44}$. Równo-

\footnotetext{
${ }^{42}$ Por. Kulikowski, Wojny Rzymu z Gotami, s. 115.

${ }^{43}$ Iordanes, Getica 146, MGH Auctores Antiquissimi V/1, 96, thum. Zwolski, s. 116.

${ }^{44}$ Por. tamże 144-145, MGH Auctores Antiquissimi V/1, 95-96, thum. E. Zwolski, s. 115-116;
} 
cześnie zwycięstwa odnoszone nad zbuntowanymi barbarzyńcami w polu dały Teodozjuszowi prawo do święcenia triumfu nad Gotami ${ }^{45}$. Przy okazji pojawia się u Pawła Orozjusza (ok. 385 - przed 423) informacja, że grupa Wizygotów związana z Atanarykiem, ujęta męstwem i dobrocią Teodozjusza, przeszła na służbę rzymską. Miało to być konsekwencją zawartego przedtem między Teodozjuszem a Atanarykiem foedus ${ }^{46}$. Nie dysponujemy żadnymi konkretami, co do zasad zawartego porozumienia, jednak nie mogły one odbiegać od zasad foedus zawartego później ze zrewoltowaną częścią Terwingów, którzy w latach 90. IV w. skupili się wokół Alaryka I. Przezorna polityka Teodozjusza I wobec Wizygotów jest dobrze widoczna na podanym właśnie przykładzie. Jeżeli założymy, że foedus z ludźmi Atanaryka poprzedził ,wielki” foedus z 382 roku $^{47}$, to niewątpliwie mamy do czynienia z rozsądna formułą podzielenia Wizygotów z wykorzystaniem istniejących już linii konfliktu wewnętrznego pomiędzy „grupą Atanaryka” i ,grupą Fritigerna”. Wstępne pozyskanie pierwszej z nich wykluczało możliwość przyłączenia się jej członków do zrewoltowanej części Terwingów, a łaskawe ich potraktowanie i ostentacyjnie przyjazne przyjęcie ich przywódcy oraz (co dla mentalności germańskiej bardzo ważne) uhonorowanie go wspaniałym pogrzebem przez Teodozjusza I było formą zawoalowanej sugestii i oferty kierowanej do skonfliktowanej z cesarstwem części Terwingów, oferty, dodajmy, wkrótce przyjętej.

Foedus z 382 r., którego zasady można odtworzyć dość dokładnie zakładał zezwolenie na osiedlenie się Wizygotów na terenie cesarstwa, jednak z zastrzeżeniem, że ziemia oddana im pod zasiedlenie pozostaje formalnie własnością państwa rzymskiego, co było bardzo ważne i podnoszone formalnie w czasie Justyniańskich działań na rzecz rewindykacji terytoriów Cesarstwa Rzymskiego na Zachodzie. Wizygoci nie stawali się obywatelami ani poddanymi cesarstwa. Na terenach osadniczych otrzymywać mieli $1 / 3$ ziemi lub, co bardziej prawdopodobne, 1/3 wpływów podatkowych $\mathrm{z}$ danego terytorium $\mathrm{w}$ produktach żywnościowych lub pieniądzu. Zapewniono im doraźne dostawy żywności oraz obiecano jakieś subwencje, których wysokości oraz

Zosimus, Historia Nova IV 34, 4, ed. Mendelssohn, s. 189, thum. Cichocka, s. 233; Orosius, Historiae adversus paganos VII 34, 6-7, ed. K. Zangemeister, CSEL 5, Vindobonae 1882 [reprint: Hildesheim 1967], 523, 2-8; Marcellinus Comes, Chronica IX 2 (381), ed. Th. Mommsen, MGH Auctores Antiquissimi XI, Berolini 1894, 61, 13-14.

${ }^{45}$ Por. Orosius, Historiae adversus paganos VII 34, 6, CSEL 5, 523, 2-5, Marcellinus Comes, Chronica VII 2 (379), MGH Auctores Antiquissimi XI 60, 22; tamże VIII (380), MGH Auctores Antiquissimi XI 61, 4.

${ }^{46}$ Por. Orosius, Historiae adversus paganos VII 34, 6-7, CSEL 5, 523, 2-8.

${ }^{47}$ Data sojuszu z grupą Atanaryka nie jest zupełnie pewna, wiadomo tylko, że zawarcie go nastąpiło dopiero po śmierci „sędziego". Ralf Scharf (Foederati, s. 9) datuje to wydarzenie na 382 r., jednak nie rozstrzyga, czy w 382 r. zawarto dwa następujące po sobie sojusze, czy był to ten sam sojusz, czy też może, co chyba najbardziej prawdopodobne, zasady i tryb zawierania foedus zostały wypracowane w 382 r. jako stałe i co najwyżej doszło do dwukrotnego ich zatwierdzenia i przyjęcia przez cesarstwo i dwie osobne grupy Terwingów. 
sposobu wypłacania nie udało się z pomocą źródeł ustalić. W zamian za to zobowiązywali się całym plemieniem i pod dowództwem swoich wodzów służyć militarnie cesarstwu w każdej potrzebie. Formalnie podlegali bezpośrednio rozkazom cesarza lub magistrów militum, jednak w praktyce odnotowano wiele odstępstw od tej reguły oraz przypadków cedowania uprawnień do dowodzenia foederati na niższe szczeble dowodzenia ${ }^{48}$. Także dwór zachodniorzymski przyjął, może nawet wcześniej, podobne rozwiązania. Gracjan musiał też uporać się z problemem zmierzających na zachód grup Ostrogotów, Hunów i Alanów, które powstrzymał osiedlając ich w Panonii II lub Walerii ${ }^{49}$.

Te regulacje stanowiły potem podstawę dla podobnych układów sojuszniczych, choć bardzo szybko pojawiły się u Wizygotów tendencje do rewizji zasad foedus na swoją korzyść. Zazwyczaj wykorzystywali momenty trudne dla cesarstwa. Mimo wielkiego miru jakim Teodozjusz I miał się cieszyć u Wizygotów, jeszcze za jego panowania nastąpiła pierwsza próba rewizji foedus. Korzystając $\mathrm{z}$ uwikłania wojsk wschodniorzymskich w walkę z uzurpatorem Maksymusem (ok. 340-388, cesarz od 383), a potem z maruderami z jego armii, Alaryk na czele osiadłych w Mezji Wizygotów rozpoczął rabunkowe rajdy w dorzeczu rzeki Hebrus (Marica). Walki toczone ze zmiennym szczęściem zakończył Flawiusz Stilichon (360/365? - 408), który otoczył Wizygotów i zmusił do odnowienia foedus z 382 roku. Po raz pierwszy Stilichon miał okazję zgniecenia Wizygotów Alaryka i po raz pierwszy, ale nie ostatni, tego nie uczynił, zapewne w myśl głównej linii polityki Teodozjusza I stawiającego na podporządkowywanie barbarzyńców imperium i „zagospodarowywanie” ich militarnie, a nie niszczenie, które choć możliwe pociągałoby za sobą duże straty $^{50}$. Energiczna reakcja ze strony dworu w Konstantynopolu zażegnała na pewien czas niebezpieczeństwo gockie na Bałkanach. W czasie wojny z uzurpatorem Eugeniuszem $(† 394$, cesarz od 392) zagrożenia ze strony Wizygotów na Bałkanach nie ma. Tym razem jako lojalni foedarati ciągną wraz z cesarzem na zachód przeciw uzurpatorowi i biora udział w bitwie nad Frigidusem (Wipawą) w dniach 5-6 września 394 roku. Ogromne straty w ludziach poniesione przez Wizygotów w pierwszym dniu bitwy, kiedy jako pierwsi przypuścili frontalny atak na linie wroga, wywołały wściekłość Alaryka, uważającego, że w ten sposób Rzymianie starali się wygubić lub przynajmniej znacznie osłabić Wizygotów. Teodozjusz starał się ugłaskać Alaryka, nadając mu wysoki stopień wojskowy, jednak fakt, że nastąpiło to po bitwie, a nie przed nią, pogłębił tylko urazę młodego wodza Terwingów, którego wojownicy wykrwawili się w bitwie pod rozkazami doświadczonego Gota w służbie

${ }^{48}$ Por. Wolfram, Die Goten, s. 140-141; Wilczyński, Germanie, s. 71-72.

${ }^{49}$ Por. Iordanes, Getica 141, MGH Auctores Antiquissimi V/1, 95, thum. Zwolski, s. 115. Herwig Wolfram (Die Goten, s. 139) jest zdania, że foedus Gracjana mógł być wzorem dla Teodozjuszowego z 382 r., ale wobec faktu, że znamy jedynie świadczenia ze strony rzymskiej, a nic nie wiemy o zobowiązaniach barbarzyńców nie można rozstrzygnąć, czy ma rację.

${ }^{50} \mathrm{O}$ motywach postępowania Stilichona, por. Wilczyński, Germanie, s. 119. 
rzymskiej, Gainasa ${ }^{51}$. Jeżeli przyjmiemy założenie, że Alaryk mógł być synem Alawiwa, to wydarzenia nad Wipawą były, obok śmierci ojca, kolejną głęboką traumą na stałe pozostawioną w pamięci wodza Wizygotów. Jednak autorytet Teodozjusza I i jego popularność wśród Terwingów spowodowały, że na razie jeszcze rząd cesarski utrzymał kontrolę nad gockimi sojusznikami.

Śmierć Teodozjusza I w Mediolanie 17 stycznia 395 r. otwiera nowy rozdział w polityce dworów wschodnio- i zachodniorzymskiego wobec Wizygotów na Bałkanach, który to rozdział odpowiada trzeciej z zasygnalizowanych na początku artykułu faz. Wzruszająca w swej naiwności jest relacja Jordanesa, że po śmierci ,przyjaciela pokoju i ludu gockiego” jego synowie Arkadiusz (377-408, cesarz od 383) i Honoriusz (384-423, cesarz od 393) popychali imperium ku zgubie pędząc rozwiązłe życie i szczędząc Gotom darów, przez co wzbudzili taką odrazę wśród walecznych wojowników, że ci wybrali sobie królem Alaryka ${ }^{52}$. Oczywiście rozwiązłość jedenastoletniego (!!!) Honoriusza i osiemnastoletniego Arkadiusza nie poruszała chyba zbytnio Terwingów, jednak sygnalizowane wstrzymanie lub zmniejszenie „darów” na pewno plemię niepokoiło i mogło być sygnałem nowego kursu w polityce dworów cesarskich. Akurat w tym przypadku można w pełni odpowiedzialnie mówić o polityce dworów, a nie cesarzy, ponieważ żaden z synów Teodozjusza I nie rządził samodzielnie. U boku każdego z nich stanął potężny opiekun i to właśnie owi tutores, czyli Stilichon na Zachodzie i Flawiusz Rufin (355-395) na Wschodzie, kształtować mieli linie polityki obydwóch dworów. Ani jeden ani drugi nie był zdecydowanie wrogi Gotom, więc wątpliwe, by ograniczenie „darów” nastąpiło na ich rozkaz. Możliwe, że przyczyną była nadgorliwość urzędników niższego szczebla lub po prostu zamieszanie związane z wyprawą przeciw Eugeniuszowi i śmiercią Teodozjusza I. Dodatkowym faktorem przyspieszającym wyniesienie Alaryka mogła być inwazja Hunów na Trację zimą 394/395 roku. Wprawdzie przerażający Wizygotów skośnoocy jeźdźcy opuścili z łupami Trację jeszcze przed topnieniem lodów, ale wiara w moc ochronną rzymskiego ramienia znacznie się zachwiała ${ }^{53}$. Budzący zaufanie Teodozjusz I, *Piudans szanowany przez Gotów nie żył, a żaden z jego sy-

${ }^{51}$ O przyznaniu stopnia: Socrates, HE VII 10, 1, ed. G.Ch. Hansen, GCS NF 1, Berlin 1995, 355, thum. S. Kazikowski: Sokrates Scholastyk, Historia Kościoła, Warszawa 1972, 448. Dla Alaryka kamieniem obrazy było już to, że mimo iż był w tym okresie na pewno niekwestionowanym przywódcą większości Wizygotów i w zasadzie to on, w myśl założeń foedus, powinien był dowodzić, został jednak od dowództwa nad gockimi sojusznikami odsunięty, a Teodozjusz I oddał wojska sprzymierzone pod rozkazy sprawdzonym wodzom Alanowi Saulusowi i Gotowi Gainasowi. Oprócz nich wymieniony jest też Armeńczyk Bakuriusz, jednak najbardziej prawdopodobne jest, że bezpośrednio nad Wizygotami dowództwo przejął Gainas (Zosimus, Historia Nova IV 57, 2-3, ed. Mendelssohn, s. 213, thum. Cichocka, s. 257-258; Ioannes Antiochenus, Fragmenta quae supersunt omnia 212, 2, rec., Anglice vertit, indicibus instruxit S. Mariev, CFHB Series Berolinensis 47, Berolini 2008, 384).

${ }^{52}$ Por. Iordanes, Getica 146, MGH Auctores Antiquissimi V/1, 96, thum. Zwolski, s. 116.

${ }^{53}$ Por. Wilczyński, Germanie, s. 123-124, spec. nota 43. 
nów - zdaniem wojowników - na taką godność nie zasługiwał. Wyniesienie Alaryka I do godności królewskiej było zjawiskiem nowym, jednak nie ma wątpliwości, że w tych okolicznościach Wizygoci chcieli silnego przywództwa. Niechętny Rzymianom przedstawiciel rodu Balthów postrzegany był jako najlepszy obrońca plemiennych interesów ${ }^{54}$.

Bunt Alaryka i jego pojawienie się pod murami Konstantynopola kompletnie zaskoczyło dwór wschodniorzymski. Rufin, działając w imieniu cesarza Arkadiusza nie myślał nawet o obronie, zresztą większość armii wschodniej, która odeszła do Italii z Teodozjuszem I, ciągle w niej pozostawała. Król Wizygotów nie zamierzał szturmować murów stolicy. Rozbił obóz w jej pobliżu i czekał na oferty ze strony Arkadiusza. W imieniu cesarza rokowania prowadził Rufin, który przy okazji pokazał, że dwór wschodni jednak nauczył się czegoś o właściwym podejściu do Gotów. Prefekt przybył na rokowania w gockim stroju z mieczem u boku. Świadczy to o sprycie Rufina i świadomości, że dla Gotów mężczyzna nieuzbrojony nie jest godny uznania za człowieka wolnego. Stając przed Alarykiem I jak równy przed równym z jednej strony zaznaczył swój status i powagę urzędu, ale z drugiej wysłał do króla dyskretny sygnał, że szanuje zwyczaje jego ludu i choć formalnie może nie jest jeszcze gotów uznać jego królewskiego tytułu, ale widzi w nim ważnego partnera politycznego ${ }^{55}$. Pozostaje do dziś zagadka, czy ustalono wtedy nowe zasady foedus i czy Alaryk I otrzymał już wtedy rangę magister militum per Illyricum. Nie ma na to żadnych dowodów, ale przebieg inwazji gockiej na Grecję po odstapieniu od Konstantynopola wydaje się w pewnych przypadkach ten fakt potwierdzać. Przemarsz przez Helladę przebiegał dość gładko. Garnizony rzymskie na północy Półwyspu Bałkańskiego praktycznie nie stawiały Wizygotom oporu i dopiero trudności z broniącymi się Tesalami zmusiły Alaryka do obejścia ich terytorium ${ }^{56}$. W okolicach Olimpu Wizygotom zastąpiły drogę wojska Stilichona, który uważając się za opiekuna obydwóch cesarzy usiłował powstrzymać barbarzyńców plądrujących Grecję. Jak słusznie zauważa Herwig Wolfram, jeżeli Alaryk był już magister militum per Illyricum, to na dobrą sprawę interwencja Stilichona mogła nosić znamiona jeżeli nie rebelii, to przynajmniej ingerencji w nie swoje sprawy ${ }^{57}$. Po raz pierwszy pojawiła się w praktyce politycznej dworów zachodniego i wschodniego głęboka rysa. Teoretycznie istniało coniuctissimum imperium,

\footnotetext{
${ }^{54}$ Źródła rzymskie niechętnie używają w stosunku do Alaryka tytułu królewskiego, szczegól-

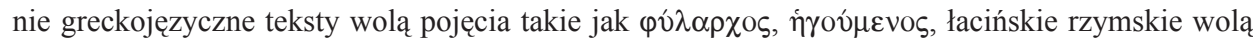
$d u x$, a łacińskie związane z dworem gockim i Gotami używają rex. Sami Wizygoci mogli stosować nazwy * reiks lub *kunig. Choć tytulatura jest rzeczą ważną, to jednak pierwszorzędne znaczenie ma fakt, że od Alaryka I Wizygoci podlegali władzy królewskiej i za jedynego swojego przywódcę uznali najpierw samego Alaryka, a potem jego następców, związanych z królewskim od 395 r. domem Balthów.

${ }^{55}$ Por. Wilczyński, Germanie, s. 128; Wolfram, Die Goten, s. 147.

${ }^{56}$ Por. Socrates, HE VII 10, 2-3, GCS NF 1, 355, tłum. Kazikowski, s. 448.

${ }^{57}$ Por. Wolfram, Die Goten, s. 147.
} 
a concordia augustorum gwarantowała trwałość tego konstruktu. Nie istniała jednak concordia tutorum, a to właśnie oni kierowali polityką w praktyce. I Stilichon i Rufin postrzegali Wizygotów jedynie jako instrument w ich rozgrywce politycznej. Wysłany w imieniu Arkadiusza nakaz odesłania do Konstantynopola wojsk wschodniorzymskich, pozostających ze Stilichonem, praktycznie uniemożliwił okiełznanie Alaryka i zmusił opiekuna Honoriusza do spiesznego odwrotu. Rufin otwarł w ten sposób Alarykowi drogę na południe Grecji, a sam przywołał swoją śmierć, bo prowadzone przez Gainasa wojska wschodnie zamordowały prefekta po przybyciu do stolicy ${ }^{58}$. Zmiana opiekuna Arkadiusza, którym został eunuch Eutropiusz (†399) niewiele zmieniła w stosunkach między Zachodem a Wschodem, rywalizacja opiekunów trwała bowiem nadal, Alaryk zaś bez większych trudności przeszedł niebronione Termopile ${ }^{59}$ i przez Beocję dotarł do Attyki. Same Ateny uniknęły całkowitej grabieży, ale nic nie uchroniło przed nią Eleusis. Rzymska obrona nie wykorzystała możliwości blokady Istmu, więc Wizygoci rozlali się szeroko po Peloponezie łupiąc Korynt, Argos, Spartę, Mykeny i Olimpię ${ }^{60}$. Dopiero na pogórzu Foloe w Elidzie ponownie zastapił im drogę Stilichon z korpusem zachodniorzymskim przerzuconym drogą morską. Podobnie jak w 391 i 395 r. obległ Wizygotów Alaryka i odciąwszy drogi zaopatrzenia w żywność i wodę czekał na poddanie się wroga. Doświadczony wódz i mąż bratanicy Teodozjusza I daleki był od myśli zniszczenia gockich foederati, lecz chciał zmusić ich do posłuchu i być może odnowić foedus na korzystnych dla siebie warunkach. Dwór wschodni i tym razem uznał interwencję Stilichona niemal za agresję i wrogą ingerencję na terenie, który zdaniem dworzan w Konstantynopolu nie podlegał kompetencjom zachodniego magistra militum. Umiejętnie rozpalone zarzewie buntu w Afryce zmusiło Stilichona do szybkiego odwrotu i znowu Alaryk uniknął o włos upokorzenia. Przeniósł swoje wojska do Epiru i tam doczekał się wreszcie w pełni oficjalnego mianowania na magistra militum per Illyricum (9 lipca 397 ${ }^{61}$. Niewykluczone, że de facto potwierdzono jedynie oficjalnie ustalenia z 395 roku. Jako magister militum per Illyricum Alaryk nabywał nie tylko prawa do dowodzenia wojskami ${ }^{62}$ na tym terytorium, ale - o co mu przede wszystkim chodziło - miał prawo gwarantowanej aprowizacji i być może korzystał z pracy cesarskich zakładów produkujących

${ }^{58}$ Por. Zosimus, Historia Nova V 7, 5-6, ed. Mendelssohn, s. 224-225, thum. Cichocka, s. 271-272.

${ }^{59}$ Por. tamże V 5, 6-7, ed. Mendelssohn, s. 222, tłum. Cichocka, s. 268-269.

${ }^{60}$ Por. tamże V 6, 1-5, ed. Mendelssohn, s. 222-223, thum. Cichocka, s. 269-270.

${ }^{61}$ Por. Wolfram, Gotische Studien, s. 146 (podstawa źródłowa w nocie 32).

${ }^{62}$ Zachodzi pytanie o jakie wojska chodziło i czy w ich skład wchodziły jakiekolwiek inne oddziały poza wojownikami Alaryka. Émilienne Demougeot (1910 - 19 VI 1994) (La formation de l'Europe et les invasions barbares, t. 2, cz. 1: De l'avènement de Dioclétien (284) à l'occupation germanique de l'Empire romain d'Occident (début du VIe siècle), Collection Historique, Paris 1979, 167) wyraża opinię, że w omawianym czasie armia Illyricum nie istniała, a więc Alaryk nie mógł dowodzić żadnymi oddziałami poza własnymi. 
uzbrojenie $^{63}$. W stosunkach wizygocko-rzymskich nastapił czas kilkuletniego spokoju i stabilizacji.

Pewnym cieniem na postrzeganie Wizygotów Alaryka przez dwór wschodniorzymski mogły kłaść się wypadki związane z buntem Gainasa ${ }^{64}$, opanowaniem przez niego Konstantynopola i wypędzeniem jego gockich oddziałów ze stolicy przez wzburzony lud. Wprawdzie z Gainasem rozprawił się w bitwie pod Konstantynopolem inny Got w służbie rzymskiej, Frawitta $(\dagger 402$ lub 403), ale na dworze Arkadiusza zapanowały na pewien czas bardzo silne nastroje antygermańskie, podsycone jeszcze ideologicznie mowami Synezjusza z Cyreny (ok. 370 - ok. 414), który mało realnie, ale za to bardzo przekonywująco wzywał do wygnania z imperium wszystkich „Scytów”, czyli Gotów. W rzeczywistości jaka panowała w silnie zgermanizowanej armii rzymskiej Goci musieliby się wygnać sami, ale opanowani patriotycznym zachwytem i oderwani od rzeczywistości dworzanie Arkadiusza w swym zachwycie nie dostrzegali tego drobnego, choć niemiłego faktu. Wszystko to wpływało raczej na pogarszanie się stosunków z Wizygotami Alaryka. Podjęta przez króla w latach 401/402 wyprawa poza tereny Bałkanów, do Italii, mimo początkowych sukcesów i porządnego napędzenia strachu zamkniętemu w murach Mediolanu Honoriuszowi, zakończyła się kolejną klęską zadaną Wizygotom przez Stilichona. Alaryk atakując Italię liczył zapewne na zawarcie foedus tym razem z Honoriuszem. Spodziewał się wymusić lepsze warunki, jednak na skutek porażki został przez Stilichona wraz z całym plemieniem wyekspediowany na tereny barbarzyńców w pobliżu Panonii i Dalmacji ${ }^{65}$. Możliwe, że po zadanej Alarykowi klęsce Stilichon zawarł z królem nowy foedus na podyktowanych przez siebie, twardych warunkach ${ }^{66}$.

${ }^{63}$ Claudianus (De bello Pollentino sive Gothico 535-544, rec. Th. Birt, w: Claudianus, Carmina, MGH Auctores Antiquissimi X, Berolini 1892, 279) mówi zarówno o władaniu miastami rzymskimi jak i o dostawach broni. Jako król foederati nie miał takich praw, jedynie jako magister militum. Słuszna jest jednak uwaga Herwiga Wolframa (Wolfram, Gotische Studien, s. 147), że w opisanym u Klaudiana zakresie kompetencji Alaryka raczej wchodził w zakres pełnomocnictw prefekta, a nie magistra militum.

${ }^{64} \mathrm{Na}$ temat buntu Gainasa, por. G. Albert, Goten in Konstantinopel. Untersuchung zur oströmischen Geschichte um das Jahr 400 n.Chr., Paderborn - München - Zürich, 1984; tenże, Zur Chronologie der Empörung des Gainas im Jahre 400 n.Chr., „Historia” 29 (1980) Heft 4, 504-508.

${ }^{65}$ Sozomenus, HE IX 4, 4, ed. J. Bidez - G.Ch. Hansen, GCS NF 4, Berlin 1995, 395, thum. S. Kazikowski: Hermiasz Sozomen, Historia Kościoła, Warszawa 1980, 588-589. Olympiodorus, Fragmenta 2, ed. R.C. Blockley, w: The Fragmentary Classicising Historians of the Later Roman Empire. Eumapius, Olympiodorus, Priscus and Malchus, vol. 2: Text, Translation and Historiographical Notes, Arca: Classical and Medieval Texts, Papers and Monographs 10, Liverpool 1983, 154.

${ }^{66}$ Jerzy Strzelczyk (Goci, s. 179) wyraża przypuszczenie, że układ taki zawarto, natomiast Herwig Wolfram (Die Goten, s. 160) jest odmiennego zdania. Osąd polskiego historyka wydaje się bardziej logiczny, ponieważ zazwyczaj w wieku V Rzymianie, jeżeli udało im się pokonać barbarzyńców, narzucali pokonanym foedus na własnych warunkach, dlaczego więc Stilichon miałby nie skorzystać z takiej okazji, tym bardziej, że w ten sposób, wiążąc Alaryka ze sobą, odbierał dworowi wschodniemu szansę ewentualnego wykorzystania Wizygotów przeciwko sobie. 
Decyzja Stilichona ulokowała Alaryka ponownie w rejonie Bałkanów. Na pewno nie był to przypadek. Wyrwawszy Wizygotów z orbity wpływów dworu wschodniorzymskiego, Stilichon sam zaczął kształtować nową koncepcję politycznego i militarnego wykorzystania niespokojnych sojuszników. $\mathrm{Z}$ nowych siedzib Wizygotów do podległej cesarstwu wschodniemu części Illyricum było bardzo niedaleko. Stosunki pomiędzy Rawenną a Konstantynopolem obciążone ciagłłą rywalizacją Stilichona z kolejnymi opiekunami i doradcami Arkadiusza były fatalne. Poparcie udzielone przez Honoriusza papieżowi w sporze wokół osoby Jana Chryzostoma (ok. 350-407) było kamieniem obrazy dla dworu wschodniego. Poselstwo zachodniorzymskie wysłane w tej sprawie zostało praktycznie internowane w Athyrze. Stilichon mógł bez obawy o reakcję Honoriusza realizować swój „plan minimum”, czyli zagarnięcie wschodniego Illyricum. W tej sytuacji Alaryk z kolei mógł spokojnie zakładać, że naruszanie granicy Illyricum i grabienie tamtejszych posiadłości nie wywoła gniewu Stilichona. W 405 r. król został oficjalnie przyjęty na etat zachodniorzymski, zostając ponownie, ale tym razem z nadania Honoriusza magister militum per Illyricum. Nowy członek zachodniorzymskiej kadry dowódczej wraz ze swym niedawnym wrogiem, a obecnie starszym kolegą Stilichonem przygotowywali się na serio do wkroczenia na podlegające Konstantynopolowi tereny bałkańskie, przy czym dysponowali na tym terenie zdecydowaną przewaga. Planowany na przełom 405/406 atak nie doszedł do skutku z powodu najazdu Radagaisa ( $†$ 406) na Italię. Po odparciu tego ostatniego powrócono do planów bałkańskich. Alaryk został posłany do Epiru ${ }^{67}$, gdzie działał dość skutecznie, na co wskazuje napływ uciekinierów z tego terenu do strefy kontrolowanej przez wojska zachodnie ${ }^{68}$. Tym razem jakaś niedyspozycja zdrowotna przerwała grabieże Alaryka. Do Italii dotarła nawet pogłoska jakoby miał umrzeć ${ }^{69}$, co może być związane $\mathrm{z}$ jednym $\mathrm{z}$ ataków malarii jakie trapiły króla ${ }^{70}$. Przekroczenie Renu przez barbarzyńców w końcu $406 \mathrm{r}$. i uzurpacja Konstantyna III znowu powstrzymały plan opanowania Illyricum w imieniu Honoriusza. Możliwe, że wiązało się to ze wstrzymaniem zaopatrzenia Wizygotów, ponieważ Alaryk, gdy wyzdrowiał, pomaszerował z Epiru do Noricum i stanął w Emonie (Lublana), żądając przez posłów od Stilichona odszkodowania za czas stracony w obronie interesów Honoriusza w Epirze. Dalszy rozwój wypadków spowodował, że Alaryk i jego Wizygoci na zawsze opuścili tereny Bałkanów i nie mieli już szansy, by odgrywać jakąkolwiek rolę w bałkańskiej polityce dworów cesarskich.

\footnotetext{
${ }^{67}$ Por. Sozomenus, HE VIII 25, 1-4, GCS NF 4, 383-384, thum. Kazikowski, s. 572-574.

${ }^{68}$ Por. Wilczyński, Germanie, s. 374, nota 199.

${ }^{69}$ Por. Zosimus, Historia Nova V 27, 2, ed. Mendelssohn, s. 250, thum. Cichocka, s. 296.

${ }^{70}$ Por. Wilczyński, Germanie, s. 143-144, nota 124.
} 
Podsumowując można stwierdzić, że zarówno w teorii politycznej, jak i w praktycznych działaniach Rzymian wobec obecności Wizygotów na Bałkanach można mówić o swego rodzaju sinusoidzie powodzeń i niepowodzeń. Od początkowych, udanych prób powstrzymywania Terwingów na granicy Dunaju w czasie pierwszej wojny gockiej Walensa, zakończonych sukcesem, linia powodzenia Rzymian spada gwałtownie w dół, by poprzez nieudolną politykę wobec migracji Gotów, brak dobrego rozeznania i kompletny brak kontroli odpowiedzialnych urzędników nad ogromną migracją osiągnąc dno pod Adrianopolem. Następnie dzięki roztropnej polityce Teodozjusza, opartej na rozumieniu potrzeb gockich imigrantów, ale i na zasadzie twardego trzymania ich w ściśle określonych ryzach, pojawia się kolejny prąd wznoszący, którego apogeum był niewatpliwie foedus z 382 r. i stosunkowo lojalna postawa Terwingów, aż do śmierci Teodozjusza. Najbardziej tragiczny dla Rzymian okres uprawiania polityki wobec Wizygotów na Bałkanach nastąpił w czasie bezwzględnej walki o kontrolę nad obydwoma nieudolnym synami Teodozjusza. Nadzieja na wykorzystanie w tym sporze Alaryka i jego Wizygotów prowadziła do przyznawania mu przez obydwa dwory coraz wyższych koncesji i doprowadzanie do sytuacji paradoksalnej, w której nie uznając formalnie władzy Alaryka króla nad terenami rzymskimi oddawano ją w znacznym stopniu Alarykowi magistrowi militum w złudnej nadziei na doraźne korzyści polityczne. Król Wizygotów był człowiekiem pojętnym i zapewne z radością wyciągał wnioski z dawanej mu nauki. Discordia tutorum (et augustorum) stawała się z biegiem czasu jego kapitałem politycznym i była głównym motorem aprecjacji wartości Alaryka w rozgrywkach dyplomatycznych. Droga jaką przeszli Wizygoci, od momentu gdy próbowali bez skutku rewidować foedus $391 \mathrm{r}$., do momentu gdy senat rzymski w 408 r. przyznał im wbrew swej woli odszkodowanie, którego żądał Alaryk stojąc obozem w Emonie, jest imponującym przykładem sprytu politycznego ich króla i kompletnie niespójnej i nieskutecznej polityki obydwóch dworów cesarskich. Linia sinusoidy wyznaczającej skuteczność tej polityki nie osiągnęła jeszcze wtedy dna. Nastapiło to dopiero w 410 r., ale nie na Bałkanach, a w kolebce imperium, w Rzymie.

\section{VISIGOTHS IN THE BALKANS REGION IN THEORY AND POLITICAL PRACTICE OF THE COURTS OF THE LATE ROMAN EMPIRE}

\section{(Summary)}

From the half of the 4-th century to the end of the 4-th century a tribe of Goths - Westgoths, played a significant role in the politics of the Eastern and Western Roman Empire courts. Activities of the emperor valens against Goths showed that 
regardless of military measures, an equally effective form of compulsion could also be economic actions. It was supported by an exceptional effectiveness of the trade embargo which use turned out to be much more effective measure which forced the barbarians to the obedience than acts of war. The initial politics of containment of the Goths invasion within the framework of the so called Gothic „wars" exercised by Valens was replaced by politic of opening of the borders of the Empire for Gothic immigrants in hope of strengthening of the Roman army with conscription of barbarous recruits. Lack of ability of mastering the crowds of newcomers and providing them a basis for peaceful existence ended with the tragedy at Adrianople in 378. A treaty of alliance of 382 seemingly met the expectations of both Parties, but for a short time only. Some attempts of the revision of the conditions of the treaty to the advantage of the Goths appeared as early as for a decade later. The key problem of the politics of the imperial courts in the Balkans at the turn of $4^{\text {th }}$ and $5^{\text {th }}$ century was the activity of the Visigothic king Alaricus who superbly made use of disagreements between Ravenna and Constantinople. Moreover, he made use of opportunities resulting from bestowing him a few times the rank of Roman magister militum. A controversial and still unexplained issue is, if Alaricus became the magister militum per Illyricum, already in 395 as result of negotiations with Rufin. Next disputable issue is, in which degree the ruler of the Visigoths led his own deliberate politics, and in which degree he remained a tool in hands of the politicians of the Eastern and Western Roman courts.

Key words: Tervingi, Westgoths, Alaric I, Roman political thought, Roman policy in the Balkans, foedera 332-405.

Słowa kluczowe: Terwingowie, Wizygoci, Alaryk I, rzymska myśl polityczna, rzymska polityka na Bałkanach, foedera 332-405.

\section{BIBLIOGRAFIA}

\section{Źródła}

Ammianus Marcellinus, Res gestae, texte établi et traduit par É. Galletier: Ammien Marcellin, Histoire, I-VI, Collection des Universités de France. Série Latine, Paris 19781999, thum. I. Lewandowski: Ammianus Marcellinus, Dzieje rzymskie, t. 1-2, Warszawa 2001-2002.

Claudianus, De bello Pollentino sive Gothico, rec. Th. Birt, w: Claudianus, Carmina, MGH Auctores Antiquissimi X, Berolini 1892 [reprint: Berolini 1961], 259-283.

Eunapius Sardianus, Fragmenta historica, ed. L. Dindorf, w: Historici Graeci minores, vol. 1, Leipzig 1870, 205-274, ed. i thum. w: Eunapios z Sardes, Zapiski historyczne.

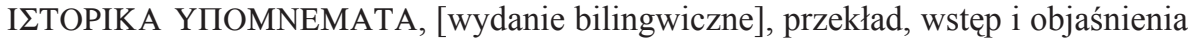
A. Pająkowska-Bouallegui, Gdańsk 2013.

IoAnnes Antiochenus, Fragmenta quae supersunt omnia, rec., Anglice vertit, indicibus instruxit S. Mariev, CFHB Series Berolinensis 47, Berolini 2008.

Iordanes, Getica, ed. Th. Mommsen, MGH Auctores Antiquissimi V/1, Berolini 1882, 53138, thum. E. Zwolski: Kasjodor i Jordanes. Historia gocka czyli scytyjska Europa, Rozprawy Wydziału Historyczno-Filologicznego 49, Lublin 1984, 91-146. 
Marcellinus Comes, Chronica, ed. Th. Mommsen, MGH Auctores Antiquissimi XI, Berolini 1894, 60-104.

Olympiodorus, Fragmenta, ed. R.C. Blockley, w: The Fragmentary Classicising Historians of the Later Roman Empire. Eunapius, Olympiodorus, Priscus and Malchus, vol. 2: Text, Translation and Historiographical Notes, Arca: Classical and Medieval Texts, Papers and Monographs 10, Liverpool 1983, 151-207.

Orosius, Historiae adversus paganos, ed. K. Zangemeister, CSEL 5, Vindobonae 1882 [reprint: Hildesheim 1967], 1-564.

Procopius Caesariensis, De bellis libri I-IV, rec. J. Havry, addenda et corrigenda adiecit G. Wirth: Procopius, Opera omnia, vol. 1, Lipsiae 1962, thum. D. Brodka: Prokopiusz z Cezarei, Historia wojen, t. 1: Wojny z Persami $i$ Wandalami, Źródła Historyczne, Kraków 2013.

Socrates, Historia ecclesiastica, hrsg. von G.Ch. Hansen, GCS NF 1, Berlin 1995, thum. S. Kazikowski: Sokrates Scholastyk, Historia Kościoła, Warszawa 1972.

Sozomenes, Historia ecclesiastica, hrsg. von J. Bidez - G.Ch. Hansen, GCS NF 4, Berlin 1995, tłum. S. Kazikowski: Hermiasz Sozomen, Historia Kościoła, Warszawa 1980.

Themistios, Orationes, Übersetzung, Einführung und Erläuterungen von H. Leppin W. Portmann: Themistios, Staatsreden, Bibliothek der Griechischen Literatur 46, Stuttgart 1998.

Zosimus, Historia Nova, ed. L. Mendelssohn: Zosimi comitis et exadvocati fisci, Historia Nova, Lipsiae 1887, Teubner, [reprint: Hildesheim 1963], tłum. H. Cichocka: Zosimos, Nowa historia, Warszawa 2012.

\section{Opracowania}

Albert G., Goten in Konstantinopel. Untersuchung zur oströmischen Geschichte um das Jahr 400 n.Chr., Paderborn - München - Zürich 1984.

Albert, Zur Chronologie der Empörung des Gainas im Jahre 400 n.Chr., „Historia” 29 (1980) Heft 4, 504-508.

Berndt G.M., Beute, Schutzgeld und Subsidien. Formen der Aneignung materieller Güter in gotischen Kriegsgruppen, w: Lohn der Gewalt. Beutepraktiken von der Antike bis zur Neuzeit, ed. H.C.J. Bömelburg, Krieg in der Geschichte 72, Paderborn 2011, 121-147.

BERndT G.M., Aktionsradien gotischer Kriegergruppen, „Frühmittelalterliche Studien” 47 (2014) 7-52.

Bursche A., The Battle of Abritus, the Imperial Treasury and Aurei in Barbaricum, „The Numismatic Chronicle" 173 (2013) 151-169.

Demandt A., Geschichte der Spätantike. Das Römische Reich von Diocletian bis Justinian 282 - 565 n. Chr., 2. Auflage, München 2008.

Demougeot É., La formation de l'Europe et les invasions barbares, t. 2, cz. 1: De l'avènement de Dioclétien (284) à l'occupation germanique de l'Empire romain d'Occident (début du VIe siècle), Collection Historique, Paris 1979.

Greef G. De, Romain Coin Hoards and Germanic Invasions AD 252-269. A Study of the Western Hoards from the Reigns Valerian, Gallienus and Postumus, ,Revue Belge de Numismatique et de Sigillographie" 148 (2002) 41-99.

KAMPERS G., Geschichte der Westgoten, Paderborn 2008.

Kulikowski M., Wojny Rzymu z Gotami od III wieku do Alaryka, tłum. Ł. Różycki, Oświęcim 2015.

SCHARF R., Foederati. Von der völkerrechtlichen Kategorie zur byzantinischen Truppengattung, Tyche 4, Wien 2001.

Schwarcz A., Die gotischen Seezüge des 3. Jahrhunderts, w: Die Schwarzmeerküste in 
der Spätantike und im frühen Mittelalter, hrsg. von R. Pillinger - A. Pülz - H. Vetters, Schriften der Balkan-Kommission. Antiquarische Abteilung 18, Wien 1992, 47-57. Speidel M., Sebastian's Strike Force at Adrianople, „Klio” 78 (1996) nr 2, 434-437.

Strzelczyк J., Goci. Rzeczywistość i legenda, Warszawa 1984.

Thompson E.A., Barbarian Invaders and Roman Collaborators, „Florilegium” 2 (1980) 71-88.

Wanke U., Die Gotenkriege des Valens. Studien zu Topographie und Chronologie im unteren Donauraum von 366 bis 378 n.Chr. Europäische Hochschulschriften III: Geschichte und ihre Hilfswissenschaften 412, Frankfurt am Main 1990.

WilczyŃski M., Germanie w stużbie zachodniorzymskiej w Vw. n.e. Studium historyczno-prosopograficzne, Prace Monograficzne - Akademia Pedagogiczna im. Komisji Edukacji Narodowej w Krakowie 299, Kraków 2001.

Wolfram H., Die Goten. Von den Anfängen bis zur Mitte des sechsten Jahrhunderts. Entwurf einer historischen Ethnographie, 3. Auflage, München - Wien 1990.

Wolfram, Gotische Studien. Volk und Herrschaft im frühen Mittelalter, München 2005. 
